\title{
GEOINFORMATICS FOR PLACES OF CRIME OCCURRENCES IN TIRUCHIRAPPALLI CITY, TAMIL NADU
}

\section{P. Mary Santhi*}

${ }^{*}$ Research Scholar, Department of Geography, Periyar E.V.R. College (Autonomous), Tiruchirappalli - 620023

\author{
S. Balaselvakumar* \\ *Assistant Professor, Department of Geography , Periyar E.V.R. College (Autonomous), Tiruchirappalli - 620 023, Affiliated to \\ Bharathidasan University, Tiruchirappalli - 620024
}

\author{
K. Kumaraswamy ${ }^{* *}$ \\ ${ }^{* *}$ ICSSR Senior Fellow - Emeritus Professor, ${ }^{* *}$ Department of Geography, Bharathidasan University, Tiruchirappalli - 620024
}

\begin{abstract}
This study is an attempt to investigate the places of crime occurrences in Tiruchirappalli city. It reveals that the places of crime occurrences are not always the same as the places of residence of criminals. The maximum of automobile theft (38.7\%) of (79 cases), in the areas of Theppakulam, Periyasamy Tower, Sarathas Kadai, Chattram Bus Stand and Priyakammla Street in Fort range, theft (36\%) of (54 cases) in and around of Central Bus Stand and Edamalaipattipudur in Cantonment range. Most of the residences of criminals are located in the northwestern of Woraiyur and central parts of Palakkarai in the city. Kernel Density Interpolation method resulted that the core of the city has been the hotspot of crime occurrences within the radius of $4 \mathrm{~km}$ from the Rockfort. This paper suggests to police department for identification of crime hotspots and crime prevention.
\end{abstract}

Keywords

Geoinformatics, Place of crime occurrences, Hotspot mapping, Automobile theft, Kernel Density Estimation

\section{INTRODUCTION}

The spatial pattern of residence of criminals charged with various sorts of crimes shows a striking variation from one part of the city to another. Criminologists and Geographers are progressively more aware of the importance of places of crime occurrences. A place is a very small area, usually a street corner, address, building, or street segment. A focus on crime places contrasts with a focus on neighborhoods. Neighborhood theories usually highlight the development of offenders. While place level explanations emphasize crime events, the place of occurrence of crime is usually not the place of residence of the criminal. There have been limited studies concerned about the places of crime occurrences such as Eck, J., and Weisburd, D. L. (2015) examined the crime places contrasts with a focus on neighborhoods to highlight the places for understanding crime, rational choice, routine activity theory and crime pattern theory; Miethe, T. D., et. al. (2001) investigated the trends in the frequency of occurrence and the effectiveness of current crime prevention strategies; Mary Santhi, P., Balaselvakumar, S., (2018- B) attempted to analyse the types and extent of crimes against women; Mary Santhi, P., Balaselvakumar, S., (2018- A) to effort on mapping and analyse of major crimes to decline crime rate; Mary Santhi, P., et. al. (2020-A) attempted to mapping and analysing the concentration of crimes against women in city level; Weisburd, D., et. al. (2004) studied the distribution of crime at street segments to view the crime trends at places over a much longer period that have examined micro places in Seattle, Washington; Mary Santhi, P., et. al. (2020-D) attempted to examine the residence of criminals from beyond and within the city; Sherman, L. W. (1995) explained the preoccupied with individuals and communities as units of 
crime analysis; Spelman and Eck, (1989) explained the concentration of crime among repeated places is more intensive than it is among repeated offenders; The index of crime concentration calculated with total crime rate of a particular police station and the total major crimes of the entire area by Mary Santhi, P. and Balaselvakumar, S., (2020); Sherman, L. W., et. al. (1989) analysed the magnitude of concentration varies by offense type; Block, R. L., and Block, C. R. (1995) examined the relationships among place, space and the specific situations; Schnell, C., et. al. (2017) analysed to understand the spatial variation of crime across urban landscapes for neighborhood-effects research variation within larger areas; Branas, C. C., et. al (2018) explored the effects of standardized, reproducible interventions that restore vacant land on the commission of violence, crime and the perceptions of fear and safety by quantitative and ethnographic analyses; Feindouno, S., et. al. (2016) created the Internal Violence Index (IVI) to compare the amount of violence at the country level with composed of internal armed conflict, criminality, terrorism, and political violence; Ceccato, V. (2005) studied the crime events in particular geographical areas at certain hours of the day and even in association with specific demographical, land use and socioeconomic aspects of the population; Mary Santhi, P., et. al. (2020-B) to map the crime occurrences in relation to demographic parameters and land use; Mary Santhi, P., et. al. (2020-C) studied the relationship between demographic parameters and crimes; Gerber, M. S. (2014) investigate the use of spatiotemporally tagged tweets for crime prediction and also to study the twitter data for crime prediction and performance based on Kernel Density Estimation (KDE); Nakaya, T., and Yano, K. (2010) to explored the Spatio-temporal patterns of crime clusters and hotspots with the aid space-time crime variants of kernel density estimation, scan statistics; Hu, Y., et. al. (2018) proposed Spatio-Temporal Kernel
Density Estimation (STKDE) method and Predictive Accuracy Index (PAI) curve to evaluate predictive hotspots at multiple areal scales; Kalinic, M., and Krisp, J. M. (2018) applied the kernel density estimation and $\mathrm{Gi}^{*}$ statistics to know the performance in detecting criminal hotspots in a city; Wang, Z., and Zhang, H. (2019) studied the distribution patterns of hot crime areas by using the spatial temporal kernel density estimation methods; Sathyaraj et al. (2010) explained the Spatio-temporal distribution of Auto Vehicle Theft through Kernel Density Estimation; Lu, Y. (2000) to discussed the hotspot concept and properties according to perception of point concentration over spatial extent by spatial pattern analysis over kernel density; Levine, N. (2006) CrimeStat software used for the spatial description, hotspot analysis, interpolation and space-time analysis for crime modeling; Hart, T., and Zandbergen, P. (2014) examined the effects of interpolation method for predictive accuracy of crime hotspot maps from kernel density estimation; Chainey, S. P. (2013) used kernel density estimation for identifying the spatial distribution and hotspot for predicting spatial patterns of crime mapping; Gorr, W. L., and Lee, Y. (2015) investigated Early Warning System (EWS) for the potential preventing crimes at temporary hotspots; Khalid, S., et. al. (2018) discussed the network hotspot detection of street crimes by integrating the NetKDE and the GetisOrd GI* statistics for bike theft, car theft, robbery, and snatching. For an effective research on places of crime occurrences, we explore the hotspot maps for the given crimes. Therefore, this study intends to help the police administration to ensure that the identification of hotspots is as accurate and effective in order to prevent crimes in the city.

\section{STUDY AREA}

Tiruchirappalli city's base map had been framed from the Survey of India (SOI) Toposheets Nos. $58 \mathrm{~J} / 9,10,13$ and 14 . The city lies between the latitudes $10^{\circ} 43^{\prime} 40^{\prime \prime}-10^{\circ} 53^{\prime} 00^{\prime \prime}$ North and 
the longitudes $78^{\circ} 38^{\prime} 14^{\prime \prime}-78^{\circ} 48^{\prime} 50^{\prime \prime}$ East (Fig. 1). It covers an area of 167.23 sq. $\mathrm{km}$ with 60 wards and four Administrative Zones namely Srirangam, Ariyamangalam, Golden Rock and Abishekapuram.

The topography of the city is relatively flat and its average elevation is 88 metres from mean sea level. Rockfort is the topmost hillock, it formed nearly 3,800 million years ago and it is marked as one of the ancient rocks in the world.
The river Cauvery and its distributary Kollidam facilitate Tiruchirappalli city also the city is fertilised by the Uyyakondan, Kudamuritti and Koraiyar canals. The land closely adjoining the Cauvery River, which crosses the city from west to east, consists of fertile alluvial soil deposits on which crops like paddy, banana and sugarcane are cultivated and in dry soil, finger millet and maize are cultivated nearby.

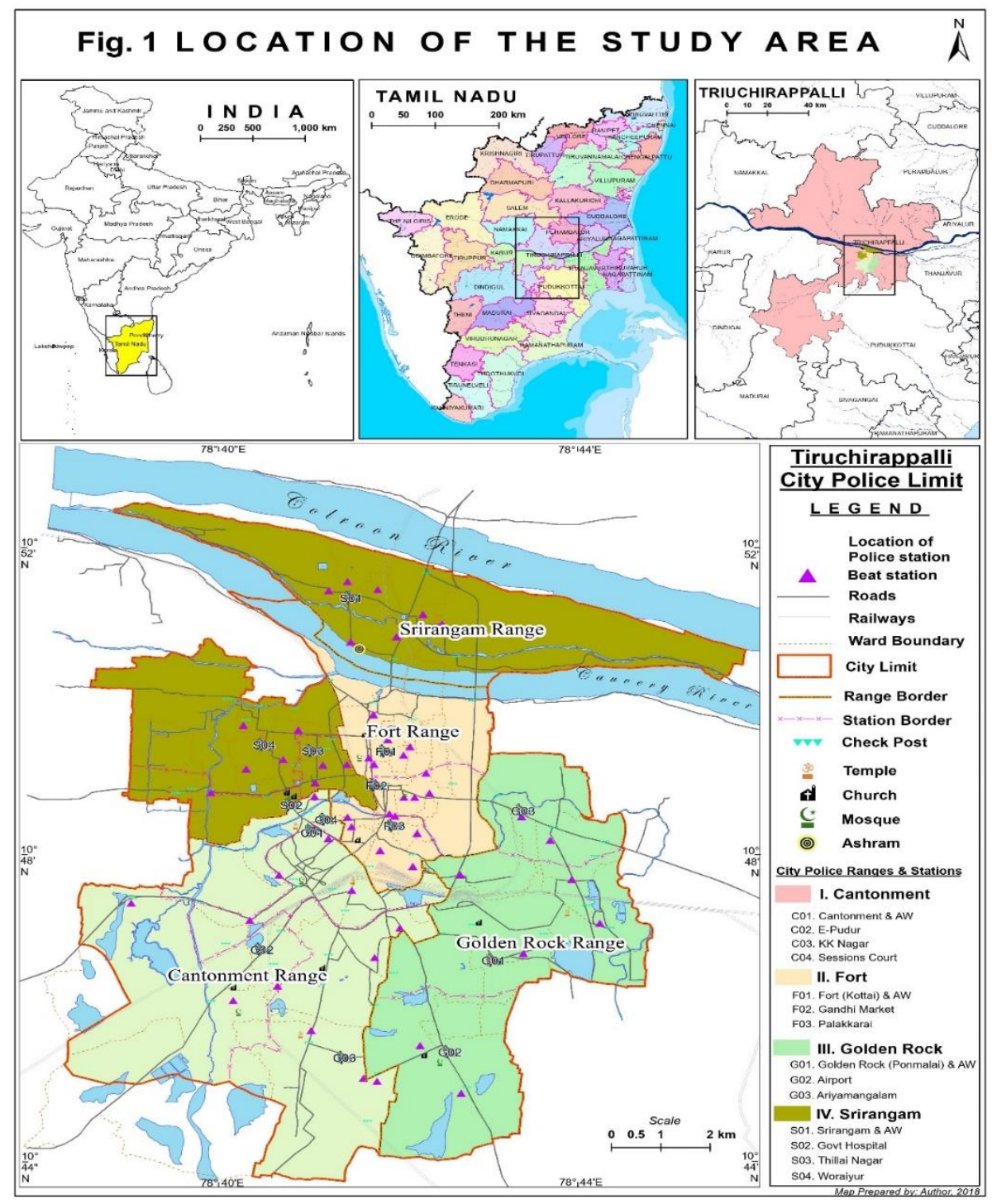

The Commissioner of Police is divided into four ranges namely Cantonment Range, Golden Rock Range, Fort Range and Srirangam Range. The jurisdiction of Commissioner of
Police System has not been extended to cover the newly expanded areas. Since the entire study depends on data from Commissioner of Police Office and 18 police stations including four 
AWPS, the study area has been restricted only to the geographical boundary of the city before expansion.

\section{METHODOLOGY}

The crime data relating to the places of occurrences for different types of crime such as robbery, theft, dacoity, automobile theft, snatching, cheating, housebreaking, counterfeit currency, crime against women, murder and male kidnapping was collected from the City Crime Records Bureau (CCRB) Tiruchirappalli City Commissioner of Police Office and from the confession statements obtained from the criminals arrested in 18 police stations jurisdiction during 2016.

Kernel Density Estimation interpolation technique was applied with the help of the places of crime occurrences to determine the hotspot of each crime in the study area. Partitioning technique was applied for grouping the crime incidents location to a specific number $(\mathrm{K})$ of clusters ellipses with isolines. (Thorndike 1953; MacQueen 1967; Ball and Hall 1970; Beale 1969; Cohen et al. 2007; Chainey et al. 2008). It can be used both for police deployment by targeting areas of high concentration of each crime incident and for prevention by targeting areas with high risk.

\section{RESULT AND DISCUSSION OCCURRENCE OF ROBBERY}

The occurrence of crime robbery was high in Srirangam range and the items that were robbed included gold chain and cash. The presence of temples, parks, hospitals, commercial areas and high-income residential areas and the commuting places with a high floating population provided more opportunity for the occurrence of robbery.
Nearly, $44.3 \%$ of robbery ( 27 cases) in the city had been reported in and around Srinivasa Nagar (near Throwpathi Amman Temple), Officers Colony near Sundar Clinic, Rajaji Street, In front of Adhi Shankara ITI, T.V.Kovil, Panchavarna-Samy Kovil Sannathi Street, Ragumaniyapuram Ground and Thennur in Srirangam range.

About $29.5 \%$ of this crime (18 cases) had been recorded in Cantonment range, which includes areas in front of Burma Colony, Collector Office Road, front of Kallukuzhi Church Ganapathi Nagar, Piratiyur, Subramaniapuram near Ushman Ali Street, K.K Nagar Raja Colony, Collector Office Road and TVS Tollgate.

Nearly, $16.4 \%$ of robbery (10 cases) had been reported in the area opposite Thiru Irudhayasamy Makkal Mandram near Therasammal Church Sangilayandapuram, Lakshmipuram, Ammaiyappan Nagar and Airport in Golden Rock range.

Only $9.8 \%$ of robbery (6 cases) had been reported in Fort range, which includes the area in front of SBI ATM-Sankaran Pillai Road, the area in front of Jana Priya Grocery Shop, Marakadai, Sofa Repair shop and Pakkali Street of Beema Nagar (Fig. 2 \& 3).

\section{OCCURRENCE OF THEFT}

The occurrence of theft was high in Cantonment range and the nature of theft was pocket-picking of items such as mobile, cash, jewel, laptop, car and cattle. The presence of commercial areas, main bus stands, railway stations, cinema theatres and high-income residential areas provided more opportunity for the occurrences of theft. 


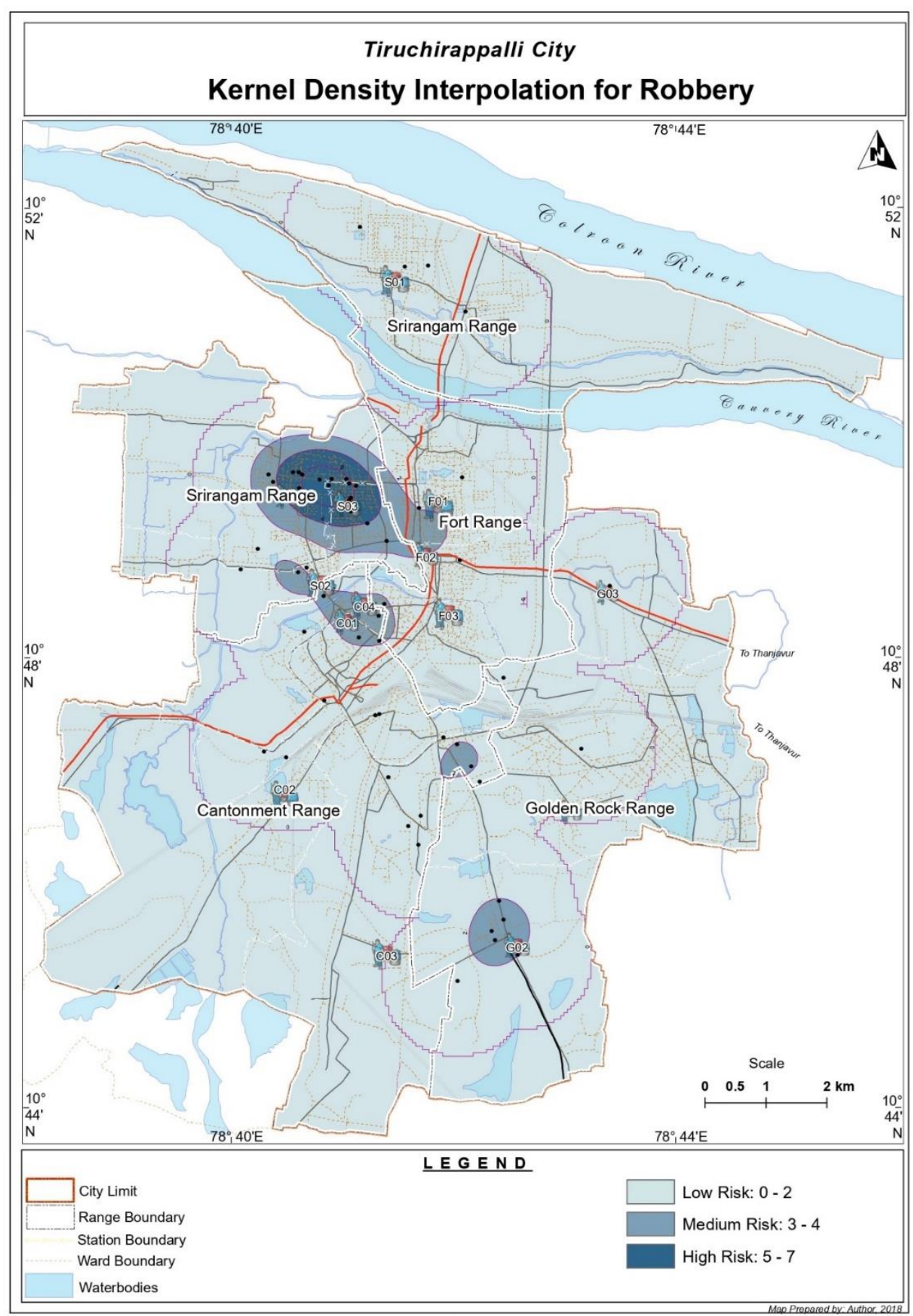

Fig 2 


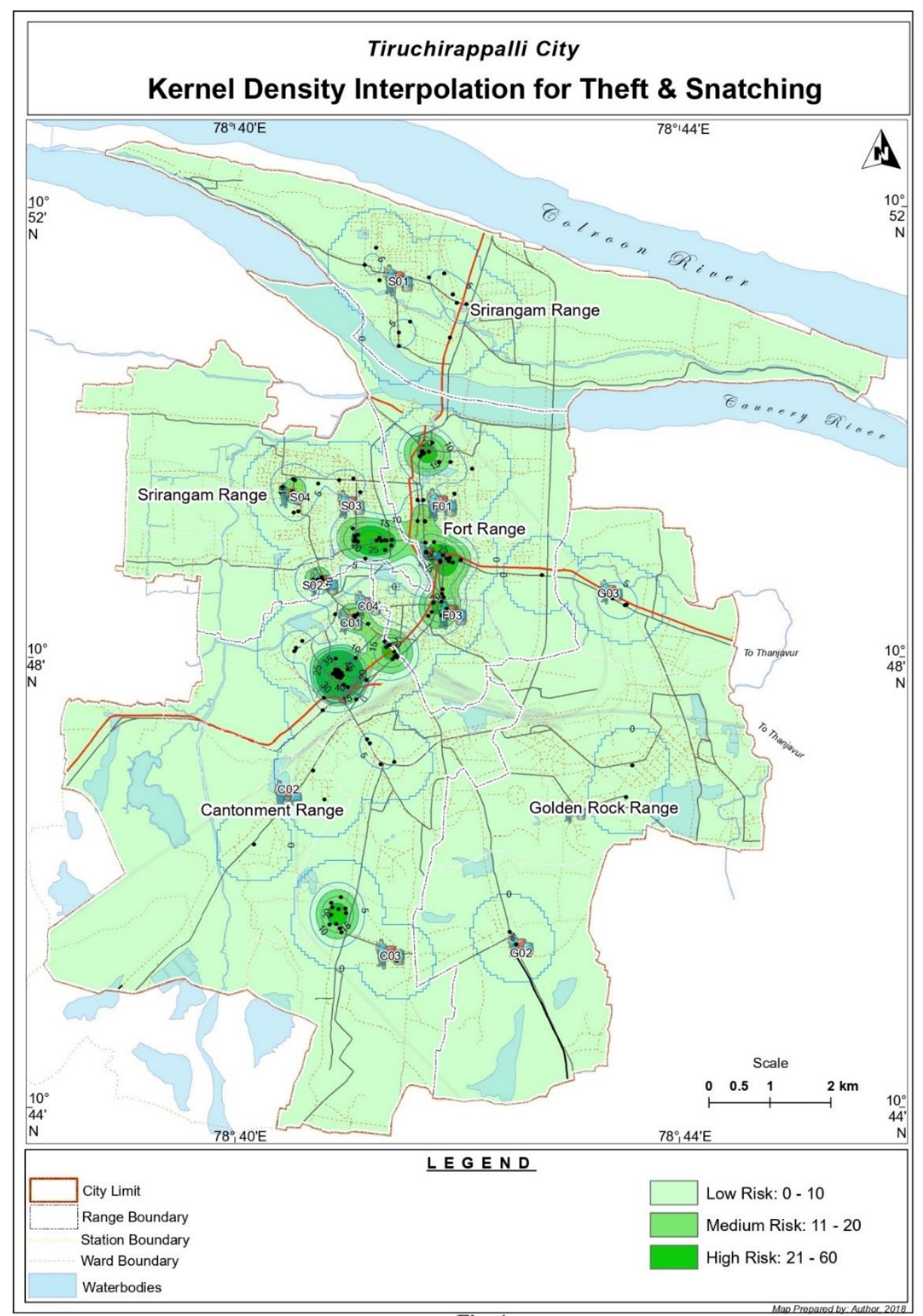

Fig. 4

Nearly, $36 \%$ of theft (54 cases) in the city had been reported in Central Bus Stand near Abirami Hotel, Trichy-Central Bus Stand, Edamalaipattipudur, Madurai Main Road near Kulanthaivel Church, Indian Bank near Marsing Pettai, near Sundarnagar Bus Stop, K.K. Nagar,
Meena Cinema Theatre and empty place near Natchathira Nagar areas in Cantonment range.

About $31.3 \%$ of theft (47 cases) had been reported in Fort range, which includes the areas of Ranjith Tea Stall Melapudur, bus stops of Marakadai, Gandhi Market and Main Guard Gate. 
Nearly, $26.6 \%$ of theft (40 cases) had been reported in Ammamandapam Bus Stop, $1^{\text {st }} \& 10^{\text {th }}$ Cross Thillainagar and Woraiyur areas in Srirangam range.

Only $6 \%$ of theft ( 9 cases) had been reported in Lakshmipuram, Ariyamangalam and Airport Bus Stops in Golden Rock range (Fig. 4).

\section{OCCURRENCE OF AUTOMOBILE THEFT}

The occurrence of automobile theft was high in Fort range. Automobile theft includes all kinds of vehicles such as cars, vans and twowheelers. The presence of commercial areas, shopping centres, main bus stands, worship places, park and market areas provided more opportunity for the occurrences of automobile theft.
Nearly, $38.7 \%$ of automobile theft (79 cases) in the city, had been reported in the areas of Theppakulam, near Head Post Office, Periyasamy Tower, North Andal Veethi, Madura Hotel, NSB Road near Sarathas Kadai, Chattram Bus Stand, Poosari Street Chinthamani Arasamara Street, Melapudur, Lilly Black near Marsinpettai, Beema Nagar, Palakkarai, Vengayamandi near Santhai Road and Priyakammla Street in Fort range.

About $30.8 \%$ of this crime (63 cases) had been reported in Srirangam range, which includes near Ammamandapam-Srirangam, Puthur near four roads, near Renga Prasath Apartment Nelson Road, Sakthi Nagar, T.V.Kovil, Malligaipuram, Pattabiraman Street, TASMAC Shop Ukkira Kaliyamman Temple, KNJ Motors Karur bypass Road and Woraiyur near Salai Road Naveen Complex areas. 


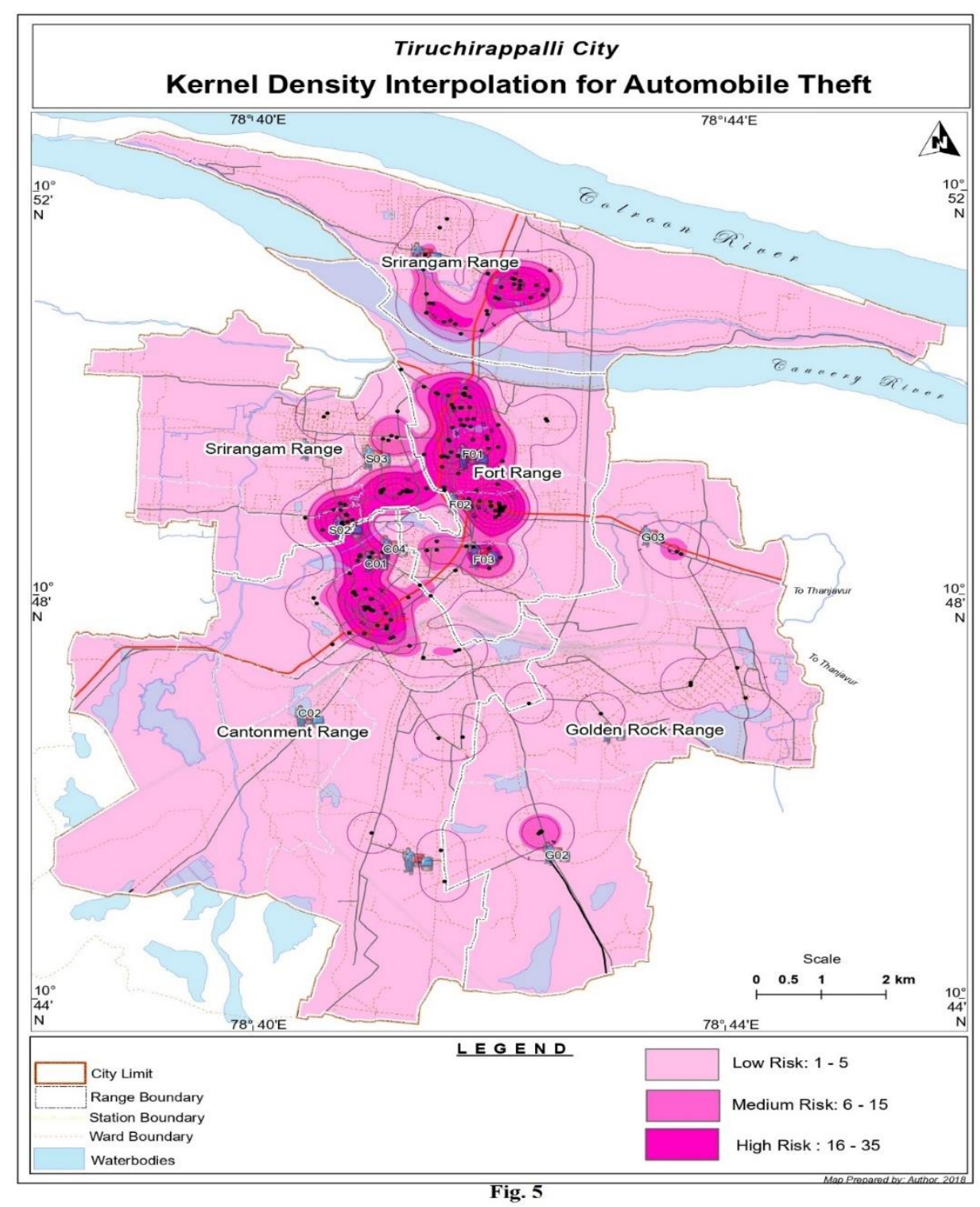

Nearly, $24.5 \%$ of automobile theft (50 cases) had been reported in the areas of Tiruchirappalli Central Bus Stand, Railway Junction, FSM-Central bus stand, Thenral Nagar, In-front of Government Law College, Khajamalai, Reliance Road near Mangalam Tower, area infront of Ayyappan Temple and Lawrence Road in Cantonment range.

About $5.9 \%$ of automobile theft (12 cases) had been reported in the airport parking areas, Thiruvalluvar Street, Kamaraj Nagar, near Ponmalai Santhai and Fish Market in Golden Rock range (Fig. 5).

OCCURRENCE OF SNATCHING
The occurrence of snatching was high in Srirangam range. The types of objects snatched were gold chains and cash. The occurrence of snatching was more in banks, cinema theatres and isolated residential houses. The crime of snatching was reported in Srirangam and Cantonment ranges only.

Nearly, $66.6 \%$ of snatching (4 cases) in the city, had been reported in the areas of Ramalinga Nagar, Woraiyur, In-front of "B" Block - KVM Sivamangala Apartment, Subramaniapuram and $1^{\text {st }}$ Street Aruna Nagar -Srirangam in Srirangam range.

About $33.3 \%$ of this crime ( 2 cases) had been reported in Cantonment range, which 
includes near Sona Meena Theatre Lane and Williams Road near Indian Bank Colony of K.K. Nagar areas (Fig. 4).

\section{OCCURRENCE OF CHEATING}

The occurrence of cheating was high in Cantonment range. The presence of commercial high-income residential areas and the commuting places with a high floating population provided more opportunity for the occurrences of cheating.

Nearly, $41.2 \%$ of cheating (28 cases) in the city, had been reported in the areas near SBI Main Branch, Head Post Office, Usman Ali Street near T.V.S Tollgate, Gandhi Nagar $1^{\text {st }}$ Street in Crawford, Thilakar Street, Ayyappa Nagar and K.K. Nagar Tiruchirappalli in Cantonment range.

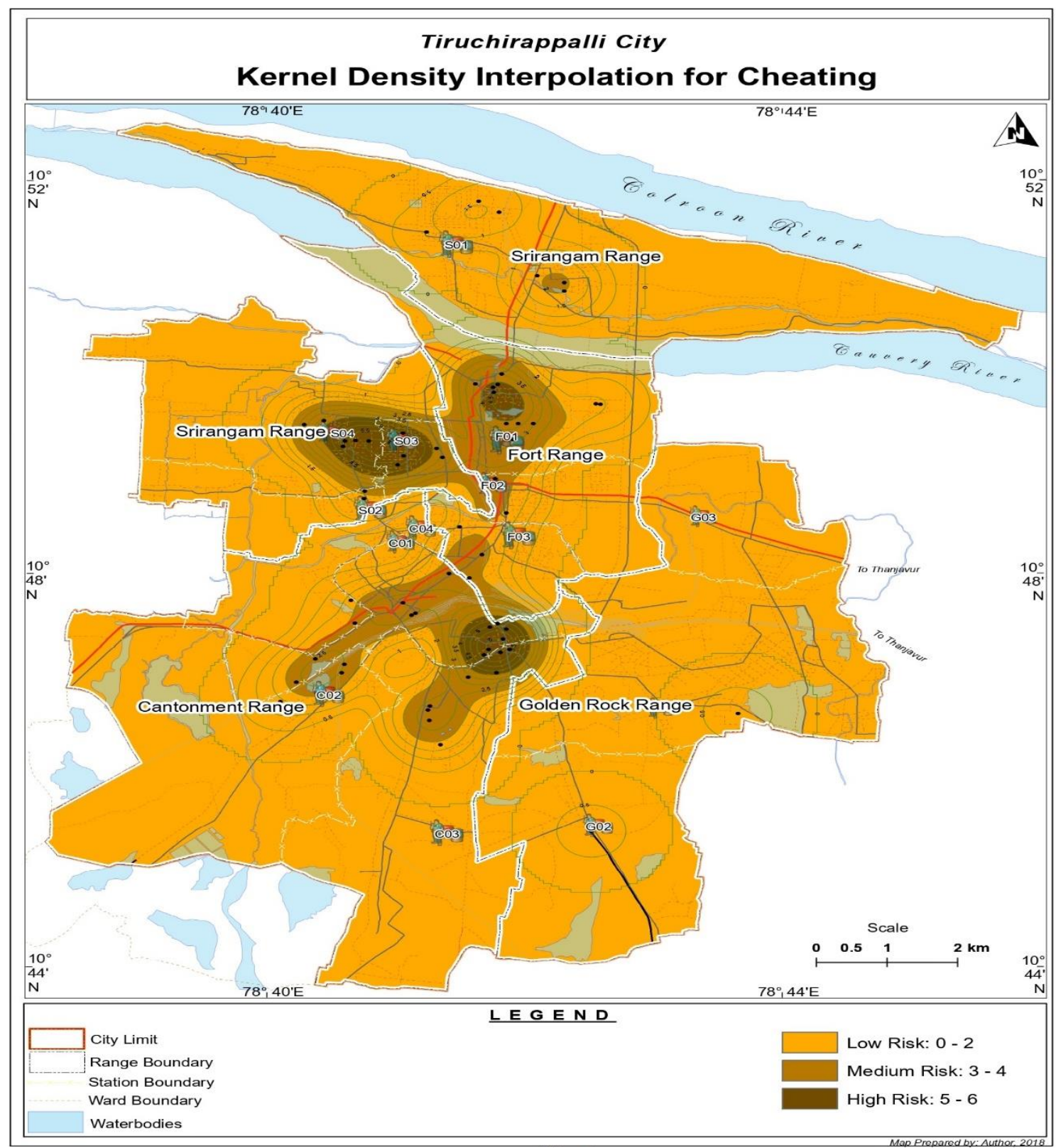

Fig. 6

About $32.3 \%$ of this crime (22 cases) had been reported in Srirangam range, which includes Thambiran Street near Narthavinayakar Kovil
Street, Canara bank Thillainagar, Palmersons near Bishop Heber School and Elil Nagar Junction areas. 
Nearly, $23.5 \%$ of cheating (16 cases) had been recorded in the areas of Heber Road Beema Nagar, Marakadai Bus Stop, Induja Aluminium Pathirakadai Periyakammala Street, Moovendhakar Nagar and Sanjeevi Nagar bypass Road in Fort range.

Only $2.9 \%$ of this crime ( 2 cases) had been reported in the areas of the airport and Kottapattu Indira Nagar in Golden Rock range (Fig. 6).

\section{OCCURRENCE OF KIDNAPPING}

The occurrence of kidnapping was high in Srirangam range. The presence of commercial, high-income residential areas and the commuting places with a high floating population provided more opportunity for the occurrence of kidnapping.
Nearly, $41.6 \%$ of kidnapping (5 cases) in the city, had been reported in Crawford Railway Bridge near, Anna Nagar near Ukarakaliyamman Kovil and $11^{\text {th }}$ cross Ruban Opposite Tea Kadai and $7^{\text {th }}$ Main Road Srinivasa Nagar in Srirangam range.

About $25 \%$ of this crime ( 3 cases) had been reported in Cantonment range that includes Sanmuganagar $8^{\text {th }}$ Cross Vayalur Road.

Nearly, $16.6 \%$ of kidnapping ( 2 cases) had been reported near Mariyamman Kovil Street near Muthaliyar Chattiram and Yathirinivash Palakkarai in Fort range.

About $16.6 \%$ of kidnapping (2 cases) had been reported near Kalaiyarangam Theatre and near Asath Nagar in Golden Rock range (Fig. 7). 


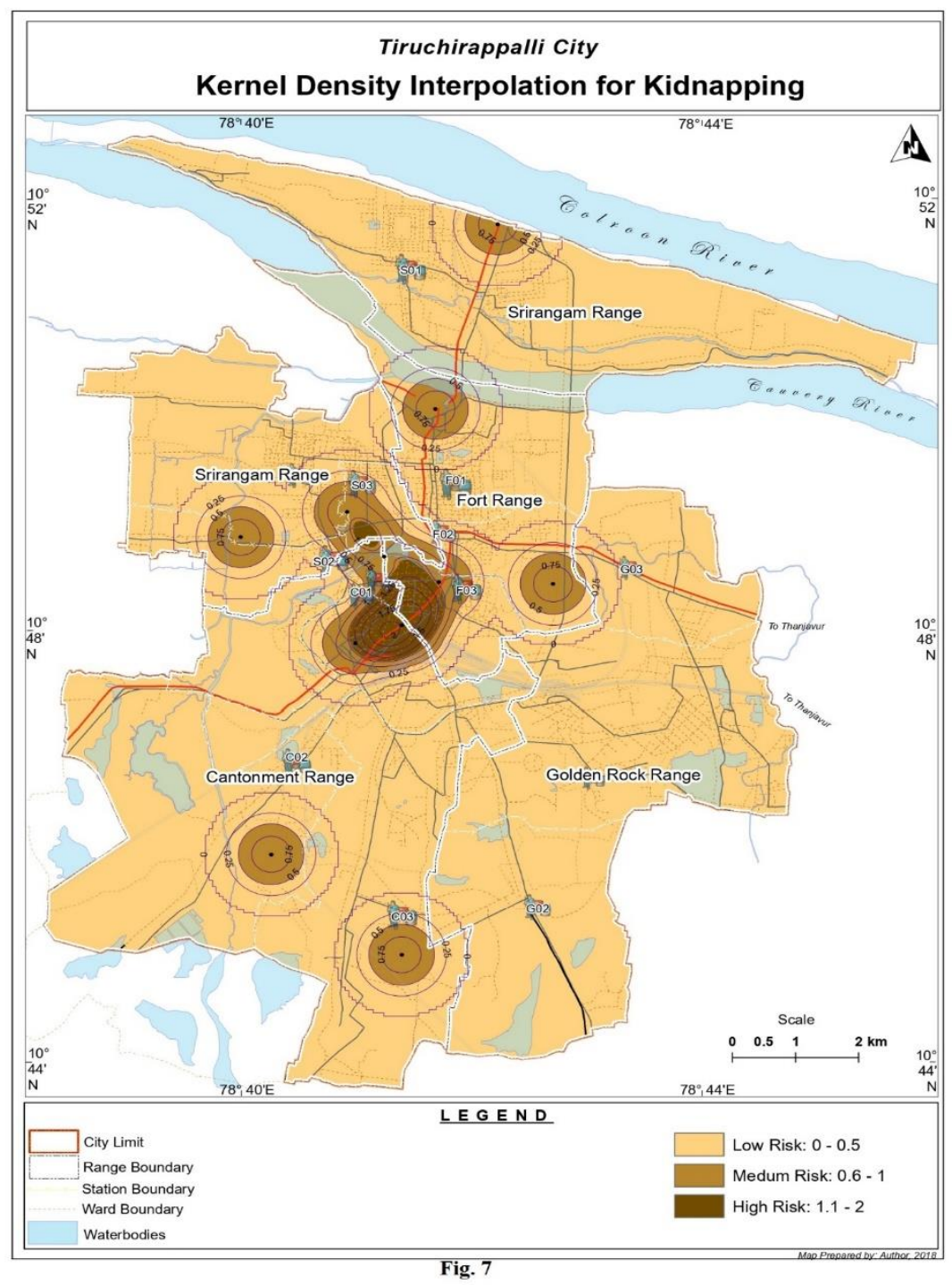

\section{OCCURRENCE OF HOUSEBREAKING}

The occurrence of housebreaking was high in Srirangam range and the items stolen during the housebreaking were jewels, cash and food items. The presence of commercial, high-income and isolated residential areas and places of worship like temples, provided more opportunity for the occurrence of housebreaking.

Nearly, 36.2\% of housebreaking (25 cases) in the city, had been reported in Pulimandapam Road, Srirangam S.V. Chari Street, Gandhi Nagar, Ukkrakali Amman Kovil Street, Ramalinga Nagar, South Extension, Woraiyur Thennur, $6^{\text {th }}$ Cut Road and $5^{\text {th }}$ Cross Srinivasa Nagar in Srirangam range.
About $30.4 \%$ of this crime (21 cases) had been reported in Cantonment range, which includes Sangilimuthu Mariyamman Temple, Usman Ali Street TVS Tollgate, New Colony, BSNL Tower Office P\&T Colony, Mannarpuram, Krishnapuram Colony-Edamalapattipudur, Vinayagar Nagar, Jaya Nagar $2^{\text {nd }}$ Cross, Karumandapam, Sundarraj Nagar and Subramaniyapuram areas.

Nearly, $24.6 \%$ of housebreaking (17 cases) had been reported in the areas of Anandha Super Market, Periya Kamala Street, Kamala Grocery Shop, Poosari St., Anna Nagar, Chinthamani, Pathai Kadai Lane Chinna Kadai Street, $4^{\text {th }}$ 
St.Viswas Nagar Old Palpannai, Kottakollai Street, Beema Nagar and Palakkarai in Fort range.

The occurrence of housebreaking was comparatively low with $8.6 \%$ (6 cases) in the areas of Thirumurugan Street, J.K Nagar, Kularpatty-Airport, Rajappa Nagar North Extension, Ariyamangalam and Fatima Street Ponmalaipatti in Golden Rock range (Fig. 8).

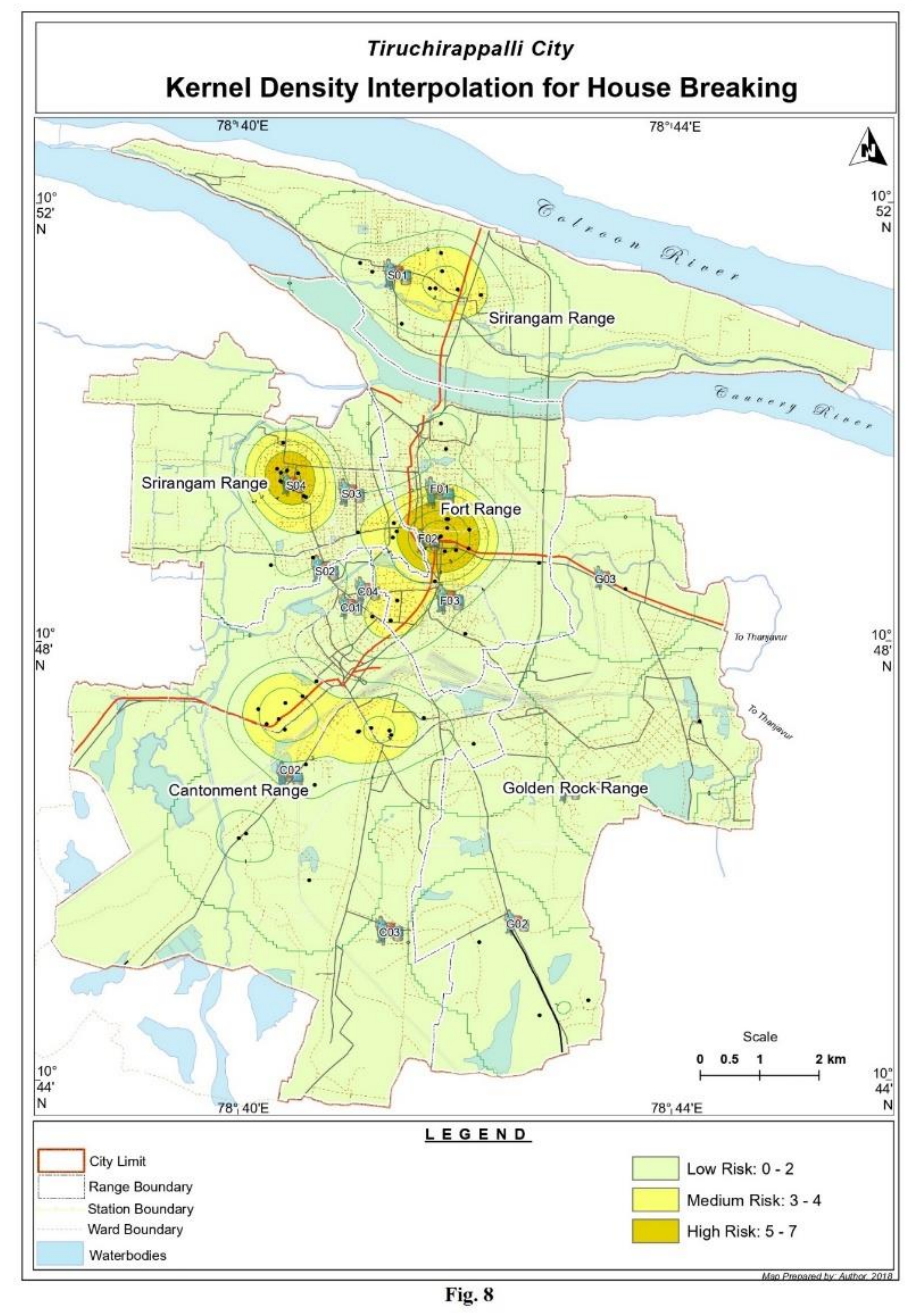

\section{OCCURRENCE OF COUNTERFEIT} CURRENCY

The occurrence of counterfeit currency (fraudsters) was high in Srirangam range area. The presence of various branches of banks (business area) and high-income residential areas provided more opportunity for the occurrences of counterfeit currency (fraudsters).
$100 \%$ of the occurrence of counterfeit currency (10 cases) in the city, had been reported only in banks namely IDBI BANK Limited, Pattabiraman Salai, Thennur-Indian Overseas Bank and SBI Bank -Tonalsh Road in Srirangam range (Fig. 9). 


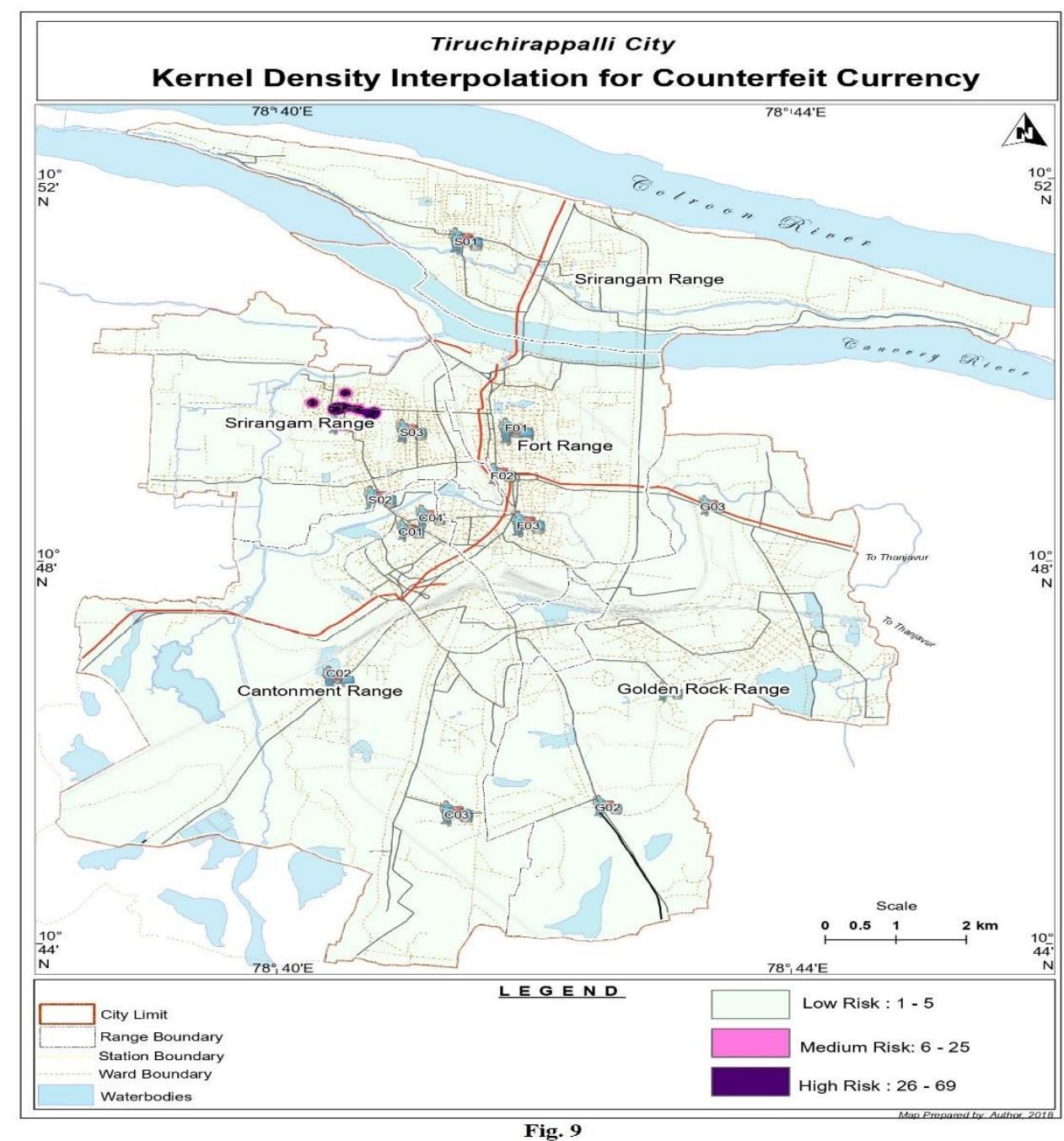

OCCURRENCE OF CRIME AGAINST WOMEN

The occurrence of crime against women was high in Srirangam range area. The presence of commercial, high-income residential areas and the commuting places with a high floating population provided more opportunity for the occurrences of crime against women. The women were targeted near malls, restaurants and colleges. Offenders generally use cars to kidnap a woman as cars support them to remain unidentified by police. The criminals, who were usually the first-timers, frequently used the dim stretches to carry out the crimes and for movement of the cars.

Nearly, $47.5 \%$ of crime against women (50 cases) in the city, had been reported in the areas of Perumal Kovil Street near Woraiyur, Natrayakonar Store-Bharathi Nagar, Thennur,
Sannathiveethi, near TV Kovil Junction, Srirangam, Theppakulam, near St. Francis Matriculation School and Ranga Nagar in Srirangam range.

About $22.4 \%$ of this crime (24 cases) had been registered in Cantonment range, which includes Vivekananthar Street, Sesayi Nagar, K.K. Nagar, MGR Nagar-Edamalapattipudur, $11^{\text {th }}$ cross Thakar Nagar-Sakthinagar Extension, Indira Street near Cauvery Nagar SIPCOT, New ColonyMannarpuram, Indira Gandhi Street and K.K. Nagar.

Nearly, $20.5 \%$ of crime against women (22 cases) had been reported in the areas of Parijatha Apartment, Varaganery- $1^{\text {st }}$ Street, Sabariyar Kovil Street, Pandarinathapuram near Beema Nagar, Malai Kottai kovil Road near Kruvikara Street and Palakkarai in Fort range. 
About $10.2 \%$ of crime against women (11 cases) had been reported in the areas of Thirumurugan Nagar, J.K. Nagar, Kajamalai-
Armary gate near Bus Stop, Vasantham Nagar and Star Nagar near Airport in Golden Rock range (Fig. 10).

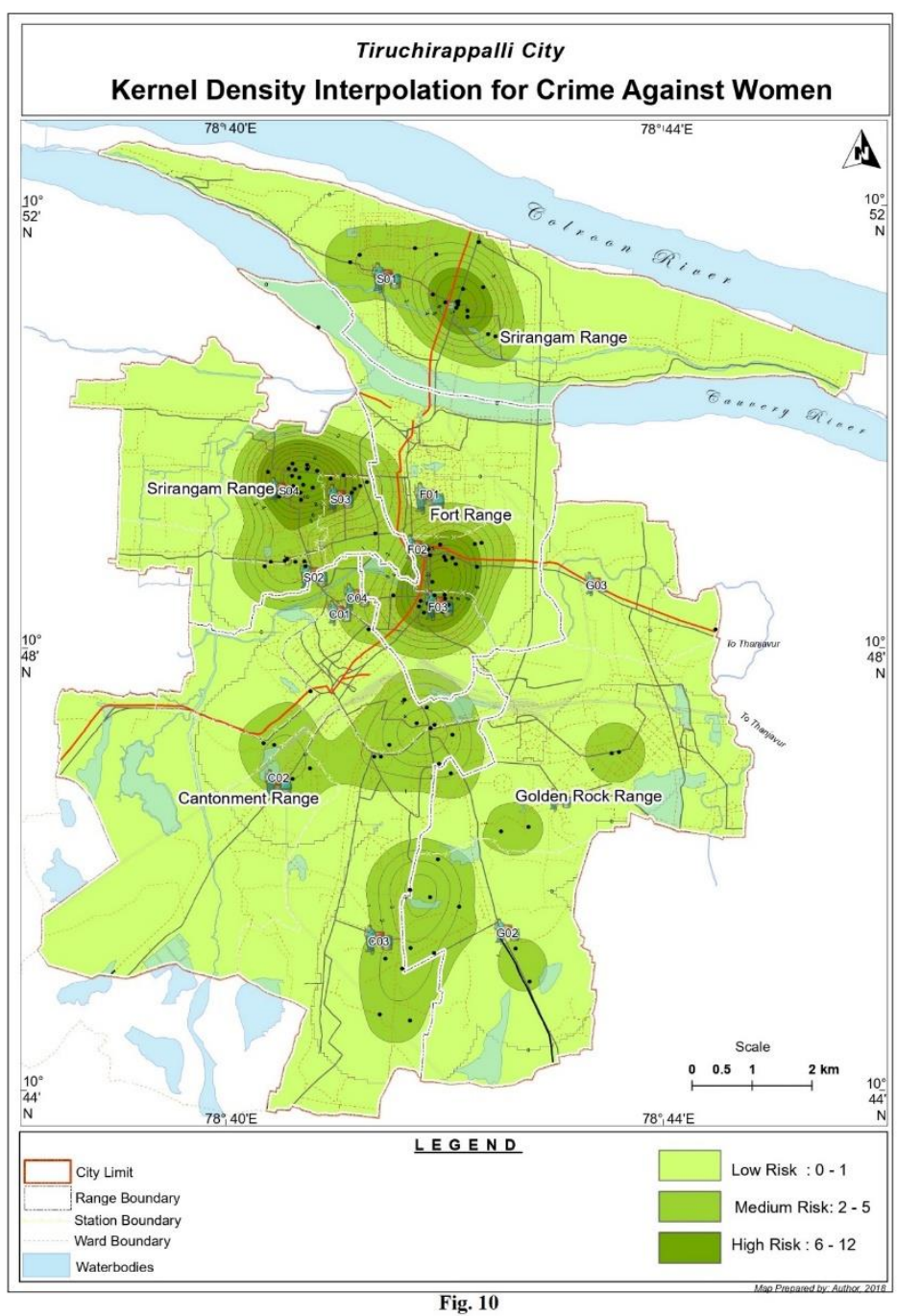




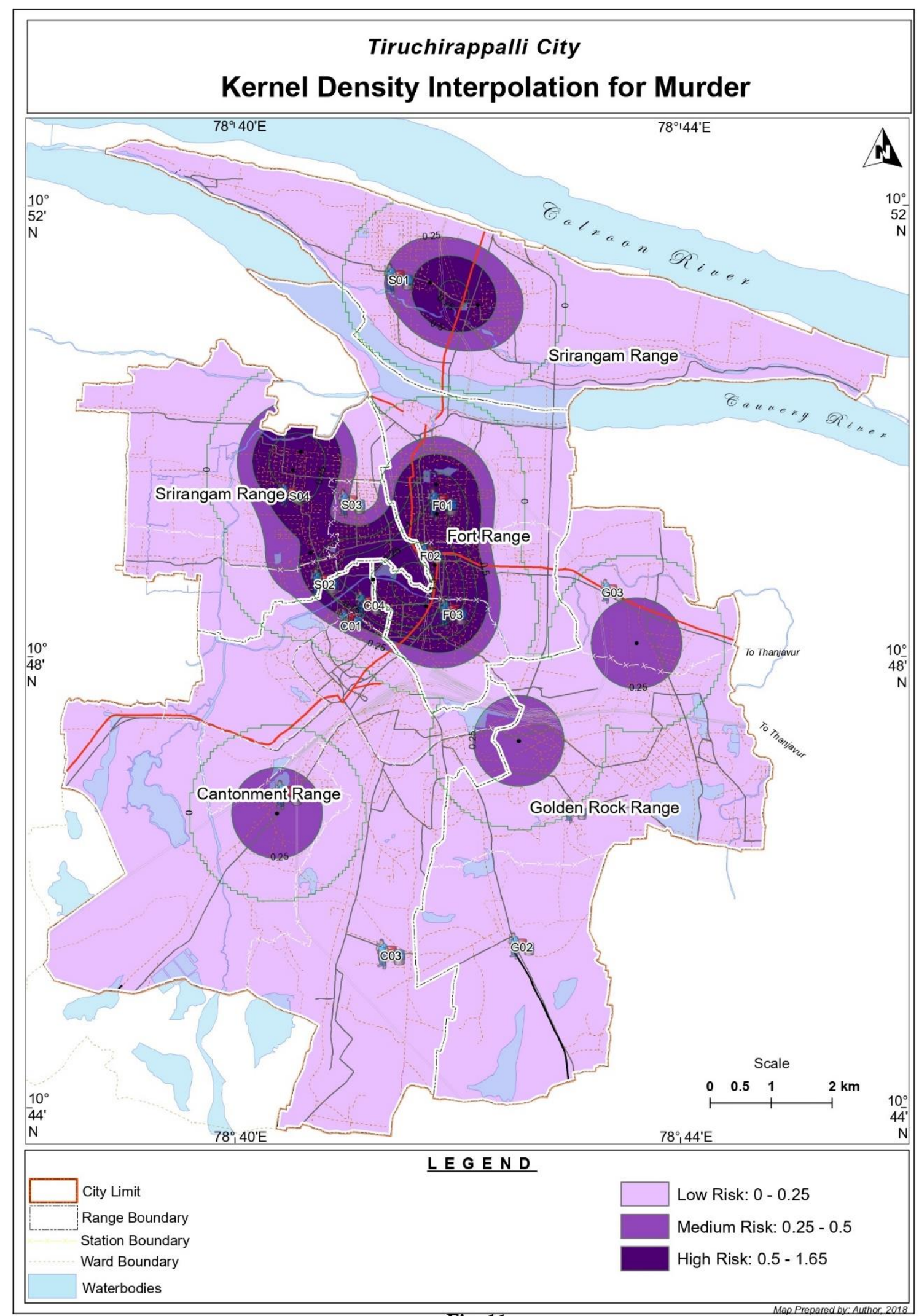

Fig. 11 


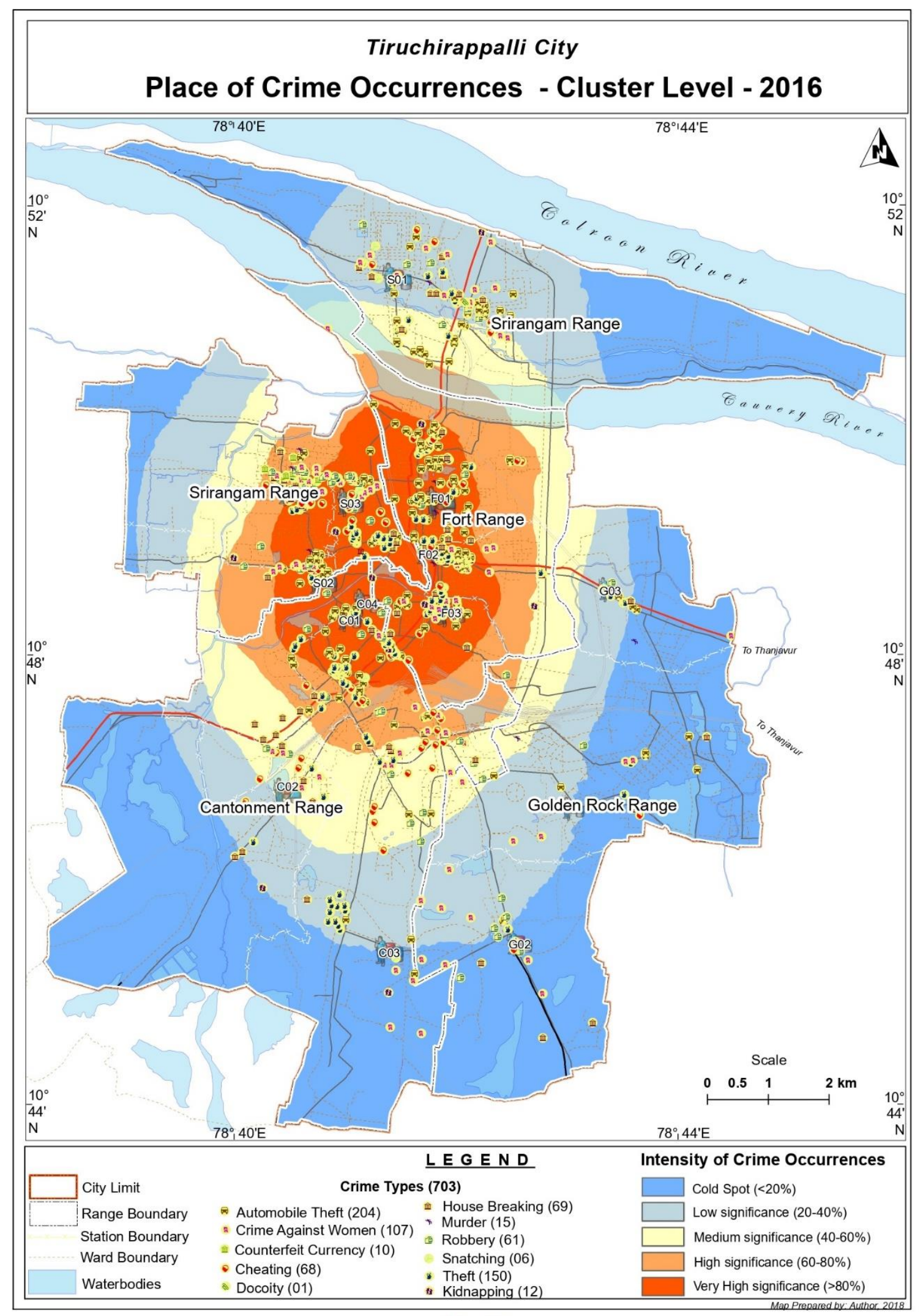

Fig. 12

OCCURRENCE OF MURDER

www.psychologyandeducation.net
The occurrence of murder was high in Fort range. The presence of shopping centres, 
administrative, temple, commercial and residential areas and the commuting places with a high floating population provided more opportunity for the occurrences of murder.

Nearly, $46.6 \%$ of murders ( 7 cases) in the city had been reported in the areas of Kamaraj Nagar North Tharanallur, Beema Nagar Konibazzar and Chinthamani Bazaar near Vennish Street in Fort range.

About $33.3 \%$ of this crime (5 cases) had been reported in Srirangam range, which includes Pudumariamman Kovil Street, Vivekanandar Salai, Metty Street, Bank Colony and T.V Kovil areas.

Nearly, $13.3 \%$ of murders ( 2 cases) had been reported in the areas of Ponmalai C Type house and M. K. Kottai Kadai Veethi near Sakthi store in Golden Rock range.

Only $6.6 \%$ of murder (1 case) had been reported in the area of Shakul Street in Cantonment range (Fig. 11).

\section{OCCURRENCE OF DACOITY}

In 2016, only one case of dacoity was recorded in Srirangam range, in Theppakulam at Srirangam police station.

\section{CONCLUSION:}

The study of the spatial pattern of criminals indicates that the places of occurrence of crimes are not always the same as the places of residence of criminals. Kernel Density Estimation interpolation technique was also applied for places of crime occurrences to find out the hotspot of each crime. Property crimes such as theft, automobile theft, cheating, housebreaking and snatching are usually committed at some distance away from the residences of criminals because the criminals' area does not provide opportunities for these pickings. Most of the criminals' areas are generally characterised by bad housing, low income, overpopulation, unemployment and slums. Most of the residences of criminals are located in the northwestern and central parts of the city. Crime against persons such as murder and crime against women, on the other hand, are committed in the area where the criminals reside owing to the way of life in these areas. Kernel Density Interpolation method reveled that overall, the core of the city has been the hotspot of crime occurrences within the radius of $4 \mathrm{~km}$ from the Rockfort (Fig. 12).

In light of the above findings, it is suggested and recommended that the commercial and residential areas of poor, lower and middleclass neighbourhoods, markets, slums and temple areas in Palakkarai, Central bus stand, Sengulam, Puttur, Daranur, Kalmandai, Thillainagar, Singaratoppu, Teppakulam, Ponnagar, Sangiliyandapuram, Milaguparai, Woraiyur, Agraharam and Mela Chintamani need to be given more attention since these areas have been identified as the high concentration of crimes in the northwestern and the central parts of the city.

The high intensity of crime against women was identified in AWPS Srirangam of Srirangam range, AWPS Fort, Fort and Gandhi Market police stations, AWPS Cantonment, Cantonment and K.K. Nagar police stations of Cantonment range and a few cases in AWPS Golden Rock. These crime-prone areas should have a mechanism to monitor the infrastructures in schools, colleges and workplaces for ensuring safety and security of women. Women police officers, in sufficient numbers fully prepared with policing infrastructure, may be appointed in these areas.

The spatial patterns of crime maps of the city must be prepared periodically and systematically so that the police officials are in a better position to know the crime-prone areas, their growth, location, direction and their trend and patterns. They should also closely work with intelligent groups of the department to reduce the opportunities that are favourable to criminals. The crime forecasting procedure developed by mapping experiences may help in identifying the possible shifts over time. 
Finally, crime can take place anywhere and everywhere and anytime with anyone, if the crime rate is to be controlled and reduced from society, nothing would work better than counselling by social reformers and psychiatrists. If people are mentally corrected and morally improved the occurrence of crimes will automatically be reduced, if not completely eradicated.

\section{ACKNOWLEDGEMENT}

We express our sincere thanks to the Commissioner of Police and the police personnel of Tiruchirappalli city for providing the necessary data for this study.

\section{REFERENCES}

[1] Ball, G.H. and Hall, D.J., (1970): “A Clustering Technique for Summarizing Multivariate Data", Behavioral Science, 12(2), 153-155.

[2] Beale, E. M. L., (1969): "Euclidean cluster analysis", A paper contributed to 37th Biennial sessions of the International statistical Institute Bulletin, United Kingdom.

[3] Block, R. L., and Block, C. R. (1995): "Space, place and crime: Hotspot areas and hot places of liquor-related crime", Crime and place, 4(2), 145-184.

[4] Branas, C. C., South, E., Kondo, M. C., Hohl, B. C., Bourgois, P., Wiebe, D. J., and MacDonald, J. M. (2018): "Citywide cluster randomized trial to restore blighted vacant land and its effects on violence, crime, and fear", Proceedings of the National Academy of Sciences, 115(12), 2946-2951.

[5] Ceccato, V. (2005): "Tools in the Spatial Analysis of Offenses: Evidence from Scandinavian Cities", GIS, 267.

[6] Chainey, S. P. (2013): "Examining the influence of cell size and bandwidth size on kernel density estimation crime hotspot maps for predicting spatial patterns of crime", Bulletin of the Geographical Society of Liege, 60, 7-19.

[7] Chainey, S., Lisa Tompson and Sebastian Uhlig (2008): "The Utility of Hotspot Mapping for Predicting Spatial Patterns of Crime", Security Journal, 21(1) 4-28.

[8] Cohen, J., Gar, W.L. and Olligschlaeger, A., (2007): "Leading Indicators and Spatial Interactions: A Crime Forecasting Model for Proactive Police Deployment", Geographical Analysis, 39(1), 105-127.

[9] Eck, J., and Weisburd, D. L. (2015): "Crime places in crime theory", Crime and place: Crime prevention studies, 4.

[10] Feindouno, S., Goujon, M., and Wagner, L. (2016): "Internal Violence Index: a composite and quantitative measure of internal violence and crime in developing countries", Development, 151.

[11] Gerber, M. S. (2014): “, Predicting crime using Twitter and kernel density estimation", Decision Support Systems, 61, 115-125.

[12] Gorr, W. L., and Lee, Y. (2015): "Early warning system for temporary crime hotspots", Journal of Quantitative Criminology, 31(1), 25-47.

[13] Hart, C.T. and Zandbergen, A.P., (2014): "Kernel Density Estimation and Hotspot Mapping: Examining the Influence of Interpolation Method, Grid cell size, and Bandwidth on Crime Forecasting”, Policing: An International Journal of Police Strategies and Management, 37 (2) 305-323.

[14] Hu, Y., Wang, F., Guin, C., and Zhu, H. (2018): “A spatio-temporal kernel density estimation framework for predictive crime hotspot mapping and evaluation", Applied geography, 99, 89-97.

[15] Kalinic, M., and Krisp, J. M. (2018, June): "Kernel Density Estimation (KDE) vs. Hot-Spot Analysis-Detecting Criminal 
Hotspots in the City of San Francisco", In: Proceeding of the $21^{\text {st }}$ Conference on Geo-Information Science.

[16] Khalid, S., Shoaib, F., Qian, T., Rui, Y., Bari, A. I., Sajjad, M., and Wang, J. (2018): "Network constrained spatiotemporal hotspot mapping of crimes in Faisalabad", Applied Spatial Analysis and Policy, 11(3), 599-622.

[17] Levine, N. (2006): "Crime mapping and the Crimestat program”, Geographical analysis, 38(1), 41-56.

[18] Lu, Y. (2000): "Spatial cluster analysis of point data: location quotients versus kernel density", University Consortium of Geographic Information Science (UCGIS).

[19] MacQueen, J., (1967): "Some Methods for Classification and Analysis of Multivariate Observations", In: Proceedings of the fifth Berkeley Symposium on Mathematical Statistics and Probability, 1(14), 281-297.

[20] Mary Santhi, P. and Balaselvakumar, S., (2020): "Spatial Analysis of Crimes in Tiruchirappalli City, Tamil Nadu”, The Indian Geographical Journal, 95(01), 136146.

[21] Mary Santhi, P., Balaselvakumar, S. and Kumaraswamy, K., (2020- D): “A Study on Criminal Residences in Tiruchirappalli City, Tamil Nadu", Wesleyan Journal of Research - An International Research Journal, 13(4-II), 112-122.

[22] Mary Santhi, P., Balaselvakumar, S. and Kumaraswamy, K., (2020-A): "Geoinformatics for Concentration of Crime Against Women in Tiruchirappalli City, Tamil Nadu", Journal of Information and Computational Science, 10(03), 832843.

[23] Mary Santhi, P., Balaselvakumar, S. and Kumaraswamy, K., (2020-B): “A Study on Crime Occurrences in Tiruchirappalli City, Tamil Nadu", Adalya Journal, 09(09), 530-546.
[24] Mary Santhi, P., Balaselvakumar, S. and Kumaraswamy, K., (2020-C): "Demographic Parameters and Crimes in Tiruchirappalli City, Tamil Nadu Using Geo-Statistical Approach", Aegaeum Journal, 08(10), 155-166.

[25] Mary Santhi, P., Balaselvakumar, S., (2018- A): "A Study on Analysis of Major Crimes in Tiruchirappalli City", International Journal of Social Science and Economic Research, 03(10), 5345-5354

[26] Mary Santhi, P., Balaselvakumar, S., (2018- B): "A Study on Crimes Against Women in Tiruchirappalli City", International Journal of Scientific Research and Review, 07(04), 01-09.

[27] McLafferty, S., Williamson, D. and McGuire P.G., (2000): "Identifying Crime Hotspots Using Kernel Smoothing," In: Goldsmith, V., McGuire, P.G., Mollenkopf, J.H. and T.A. Ross (Eds): Analyzing Crime Patterns: Frontiers of Practice, Sage Publications, California, 7786.

[28] Miethe, T. D., McCorkle, R. C., and Listwan, S. J. (2001): “Crime profiles: The anatomy of dangerous persons, places, and situations", Roxbury Publication.

[29] Nakaya, T., and Yano, K. (2010): "Visualizing crime clusters in a space-time cube: An exploratory data-analysis approach using space-time kernel density estimation and scan statistics", Transactions in GIS, 14(3), 223-239.

[30] Sathyaraj, S.R., Thangavelu, A., Balasubramanian, S., Sridhar, R., Chandran, M. and Prashanthi Devi, M., (2010): "GIS Analysis of SpatiallyReferenced Auto Vehicle Theft Crime in Coimbatore Urban, India: Visualization through Kernel Estimation", $3^{\text {rd }}$ International Conference on Cartography and GIS, Bulgaria. 
[31] Schnell, C., Braga, A. A., and Piza, E. L. (2017): "The influence of community areas, neighborhood clusters, and street segments on the spatial variability of violent crime in Chicago", Journal of quantitative criminology, 33(3), 469-496.

[32] Sherman, L. W. (1995): "Hotspots of crime and criminal careers of places", Crime and place, 4, 35-52.

[33] Sherman, L. W., Gartin, P. R., and Buerger, M. E. (1989): "Hotspots of predatory crime: Routine activities and the criminology of place", Criminology, 27(1), 27-56.

[34] Thorndike, R.L., (1953): "Who belongs in a family?", Psychometrika, 18, 267-276.

[35] Wang, Z., and Zhang, H. (2019): "Understanding the spatial distribution of crime in hot crime areas", Singapore Journal of Tropical Geography, 40(3), 496-509.

[36] Weisburd, D., Bushway, S., Lum, C., and Yang, S. M. (2004): “Trajectories of crime at places: A longitudinal study of street segments in the city of Seattle", Criminology, 42(2), 283-322. 